\title{
Vegetation dynamics of beech forests on limestone in central Germany over half a century - effects of climate change, forest management, eutrophication or game browsing?
}

\author{
Steffi Heinrichs, Wulfard Winterhoff \& Wolfgang Schmidt
}

\begin{abstract}
The aim of this study was to investigate the vegetation dynamics of suboceanic, submontane, mesic beech forests on limestone that are very rich in spring geophytes over half a century, considering changes in abiotic and biotic conditions including global climate change. Vegetation relevés sampled in the Göttinger Wald, southern Lower Saxony, Germany, between 1955 and 1960 ( $n=$ $25)$ and in $1968(n=10)$ were re-surveyed in 2009 on quasi-permanent plots. Differences in species composition, species abundance and vegetation structure were compared between inventories using detrended correspondence analysis (DCA), multiple response permutation procedure (MRPP) and the Wilcoxon signed ranks test. Forty to fifty years ago, a shrub layer was scarcely present, but is common today as a consequence of intensified hunting. An increasing abundance of Allium ursinum, Urtica dioica and Sambucus nigra and a general shift to species composition with higher Ellenberg indicator values for nitrogen can be ascribed to atmospheric nitrogen deposition. The spring geophytes A. ursinum, Corydalis cava and Leucojum vernum can also benefit from global climate change with an earlier start of the vegetation period. A shift towards more oceanic conditions, with mild winters in the past fifty years, may also have increased the competitive strength of evergreen species that are susceptible to long frost periods (e.g. Hedera helix). The resampling of the beech forest vegetation on limestone revealed that many factors have influenced the dynamics over the past half century. These include eutrophication and a reduction in roe deer browsing, but our results also indicate a possible influence of climate change on community composition. In focussing on a small dataset from a very rich sub-unit of beech forests on limestone, the positive response of the spring geophytes becomes particularly obvious.
\end{abstract}

Keywords: Allium ursinum; Ellenberg indicator value; Hedera helix; species composition change; spring geophyte; vegetation resampling.

Nomenclature: Wisskirchen \& Haeupler (1998) for vascular plants; Koperski (1999) for bryophytes.

Abbrevations: a.s.l. = above sea level DCA $=$ detrended correspondence analysis DWD $=$ Deutscher Wetterdienst; MRPP = multiple-response permutation procedure.

Received: 5 November 2010 - Accepted: 14 February 2011 - Co-ordinating Editor: Jörg Ewald.

\section{Introduction}

For centuries European forests have been affected by humans, either directly through forest management or, since industrialisation and the intensification of agriculture, indirectly by eutrophication and acid deposition (e.g. FalkengrenGrerup 1986, Bernhardt 2005). Though climatic change was present throughout the history of forests (e.g. "the Little Ice Age"; Bradshaw \& Zackrisson 1990, Huntley 1990, Campbell \& McAndrews 1993), in recent years the global climate warming has emerged as a particularly important factor influencing forest eco- systems, with frequently occuring extreme events (windthrow, drought) that lower forest stability (Overpeck et al. 1990, Wohlgemuth et al. 2008). The potential influence of global warming on forest vegetation has so far been mainly investigated by analysing species composition along temperature gradients (e.g. Van der Veken et al. 2004). Results indicate the possibility of a vegetation shift towards thermophilic and scleromorphic species, while species of cool-temperate regions may be threatened by local extinction. Actual climate-induced vegetation changes have been observed across Europe in terms of an earlier phenology
(Dierschke 2000, Fitter \& Fitter 2002, Menzel et al. 2006, Sparks et al. 2009) or species shifts to higher elevations or latitudes (Root et al. 2003, Lesica \& McCune 2004, Walther et al. 2005a, 2005b, 2007, Pauli et al. 2007, Lenoir et al. 2008, Walther 2010). Records of abundance changes at fine scales in different European forest regions as a result of climate change are however scarce (but see $\varnothing \mathrm{k}-$ land et al. 2004 and Lenoir et al. 2010) and mainly restricted to an observed spread of some evergreen species (Carraro et al. 2001, Dierschke 2005, Hilker et al. 2005, Diekmann 2010) and the early spring-species Allium ursinum 
(Ahrns \& Hofmann 1998, Böhling 2008, Schmidt 2009). Spring geophytes are especially mentioned as being sensitive to an earlier start of the vegetation period, with a lengthening of their growing season and the possibility of reproduction before canopy closure (Menzel et al. 2006). Apart from Böhling (2008) and Schmidt (2009), real evidence for their spread in the Central European forests is, however, missing as most earlier studies on vegetation dynamics focused on species as indicators of eutrophication, acidification or deer browsing (Diekmann \& Dupré 1997, von Oheimb et al. 2005, Bernhardt-Römermann et al. 2009).

The database "Temperate deciduous forests of the Göttinger Wald" (Schmidt et al. 2012; ID EU-DE-018 in the Global Index of Vegetation-Plot Databases, GIVD, Dengler et al. 2011, Jansen et al. 2011) contains 350 vegetation relevés with the first relevés recorded in 1955. This study systematically re-surveyed a small number of old relevés, first recorded between 1955 and 1968, representing a rare, but typical sub-unit of beech forests on limestone around Göttingen that is very rich in spring geophytes (especially A. ursinum, Corydalis cava, Leucojum vernum, Plates $\mathrm{A}$ and $\mathrm{B})$. It has been classified as Melico-Fagetum allietosum by Winterhoff (1960), "rich beech forest on limestone" by Schmidt (1968) and Hordelymo-Fagetum lathyretosum, Allium ursinum-variant p.p. by Dierschke (1989). This gave the opportunity to analyse especially the group of early spring species, but also the plant community in general, with regard to a changing climate in the Göttinger Wald and concurrently taking into account other conditions that might have changed during the past half century.

\section{Methods}

\section{Study area}

All the plots of this study are situated in the Göttinger Wald, a low mountain range formed on Triassic limestone near the city of Göttingen, Germany. Predominant soils in this region are shallow rendzinas with ample nutrient supply. The study area can be assigned to the suboceanic, submontane climate of the German low mountain ranges (measurements at weather station Göttingen: average yearly mean temperature $8.7^{\circ} \mathrm{C}$; average yearly precipitation sum $645 \mathrm{~mm}$ ). The climate around the study plots at altitudes between 300 to $400 \mathrm{~m}$ a.s.l. is slightly cooler with higher precipitation values (approx. $7.4{ }^{\circ} \mathrm{C}$ and $709 \mathrm{~mm}$ according to Panferov et al. 2009) compared to the mentioned weather station.

Due to ample nutrient supply and the climatic situation, limestone beech forests (Hordelymo-Fagetum lathyretosum; Dierschke 1989) are predominant. Beech is accompanied by nutrient-demanding broadleaved tree species such as Acer platanoides, A. pseudoplatanus and Fraxinus excelsior. According to Winterhoff (1960), all study sites have been forested at least since the Middle Ages.

\section{Data material and re-sampling}

Two datasets of vegetation relevés recorded in a vegetation sub-unit rich in spring geophytes were available: (i) data recorded between 1955 and 1960 on different plot sizes $\left(n=25,100\right.$ to $200 \mathrm{~m}^{2}$; Winterhoff 1960); and (ii) data from 1968 recorded on $100 \mathrm{~m}^{2}$-plots $(n=10$; Schmidt 1968). A re-survey was conducted in 2009. Plots recorded by Schmidt (1968) could be exactly relocated. Plots sampled by Winterhoff (1960) were marked on old maps, but not permanently in the field. Thus, the resurveys of these plots could only be repeated on "quasi-permanent plots" (Röder et al. 1996), that complied with the historical plot position in terms of inclination and exposition and were homogeneous in forest structure

In order to record the whole species spectrum, original vegetation surveys, as well as re-surveys were conducted twice per year (in spring, when geophytes were in full bloom, and in summer) using the scale introduced by Braun-Blanquet (1964). For species sampled in both spring and summer, the respective higher Braun-Blanquet value was considered.

Species were recorded separately for tree layer (woody species $>5 \mathrm{~m}$ ), shrub layer (woody species $<5 \mathrm{~m}>0.5 \mathrm{~m}$ ), herb layer (woody species $<0.5 \mathrm{~m}$ and nonwoody vascular plants) and moss layer.

Most of the plots first sampled in 1968 are located within a small range of the municipal forest Göttingen on a plateau and were barely affected by thinning. These plots could be exactly relocated in 2009. In contrast, plots first sampled in 1955-60 are dispersed across the whole Göttinger Wald area, which in recent years was subject to more or less intensive thinning operations. Here the resurveys could only be repeated on "quasipermanent plots". Therefore, the two datasets were analysed separately.

\section{Data analysis}

To illustrate how climatic conditions have changed in the last 50 years in the area of Göttingen, the deviation of mean monthly temperature and precipitation for the 15year periods 1955 to 1969 and 1995 to 2009 from the long-term mean (19611990) were determined based on data of the weather station Göttingen $(173 \mathrm{~m}$ a.s.l; data from the monthly reports published by Deutscher Wetterdienst DWD).

Vegetation data were transformed into mid-point values of the abundance cover degrees as follows: $\mathrm{r}=0.1 \% ;+=0.5 \% ; 1$ $=2.5 \% ; 2=15 \% ; 3=37.5 \% ; 4=62.5 \%$; $5=87.5 \%$ (Dierschke 1994). Separately for both datasets, an indirect ordination (Detrended Correspondence Analysis, DCA) was performed on arcsine transformed cover values to identify possible coherent shifts of the study plots between different inventories, based on their floristic composition. A multiple-response permutation procedure (MRPP) based on 1,000 permutations using euclidean distance was conducted to identify differences in DCA plot scores along the first two ordination axes between the two inventories. Multi-response permutation procedures are multivariate, nonparametric tests that evaluate the null hypothesis of no difference between groups (McCune \& Grace 2002).

To interpret the possible vegetation change in terms of environmental factors, cover-weighted mean Ellenberg indicator values (Ellenberg et al. 2001) were calculated for each plot and inventory and correlated with the plot scores on the first two ordination axes. Vectors of indicator values were projected into ordination diagrams to visualize ecological intepretation of axes.

Furthermore, mean species richness and mean cover values per plot of the tree, shrub, herb and moss layers were compared between observations. The same was done for single species with cover values $>1 \%$ or frequencies $>20 \%$ in at least one inventory. Frequency was calculated as the percentage of available plots in which a specific species was recorded. 


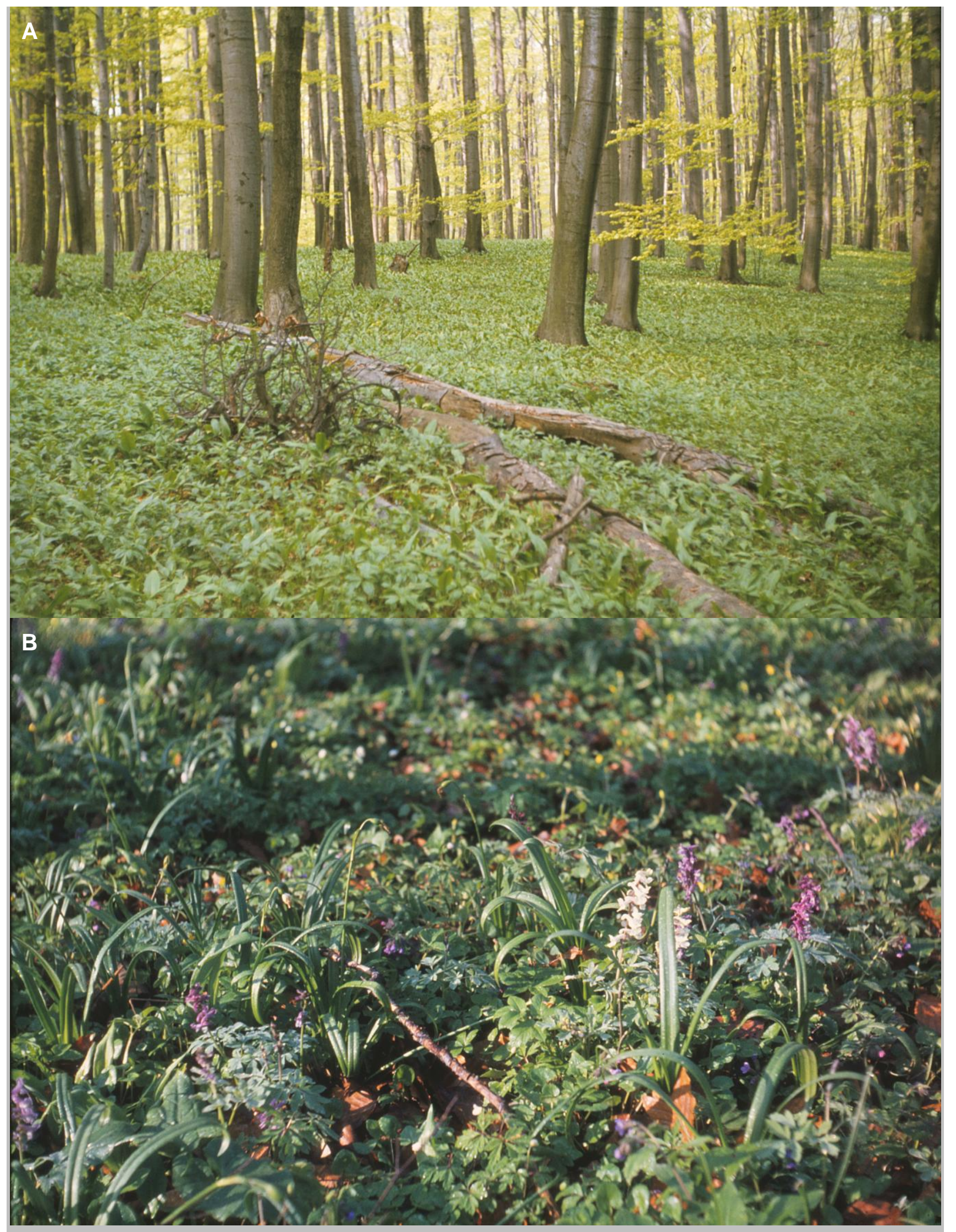

Plate: Forest ground vegetation in the Göttinger Wald characterised by A) Allium ursinum and B) Corydalis cava and Leucojum vernum (Photos W. Schmidt). 
Statistical differences in analysed parameters between the inventories were determined with the Wilcoxon signed ranks test. Results were assumed to be statistically significant at $p<0.05$ throughout the work. For all statistical analyses the $\mathrm{R}$ software was used ( $\mathrm{R}$ 2.8.1; R Development Core Team 2008). Ordination and MRPP were conducted using the package vegan ( $\mathrm{R}$ package version 1.15-1; Oksanen et al. 2008).

\section{Results}

\section{Climatic conditions}

During the time period 1955 to 1969 most monthly temperature means were lower compared to the long-term mean (1961 to 1990). In the second time period (1995 to 2009), however, in all but two months (June and December) higher temperatures were recorded compared to the long-term mean (Fig. 1a). The greatest increase compared to the time span 1961-90 was in February.

Precipitation values did not show such a clear pattern. However, the monthly amount of precipitation in February, March and May was higher during the period of 1995 to 2009 compared to the earlier time span. In contrast to this, April and the summer months from June to August were drier in the last 15 years compared to half a century ago (Fig. 1b).

\section{Species richness and cover of vegetation layers}

Both datasets display an overall increase in shrub and herb layer coverage in the last 50 years. A significant increase between the inventories 1955-60 and 2009 could be detected for the shrub layer, while the 1968 vs. 2009 comparison showed a significant increase with regard to herb layer coverage (Fig. 2). Tree layer development differed in the two datasets, with a significant decrease in the first and a slight non-significant increase in the second. Shrub and tree layer species richness showed a similar development from 1955-60 to 2009 as the respective cover values. No significant differences in species numbers could be detected between the re-survey 1968 vs. 2009.

\section{DCA ordination}

For both datasets, the DCA ordination diagram shows a directional vegetation change from the first to the recent inven-
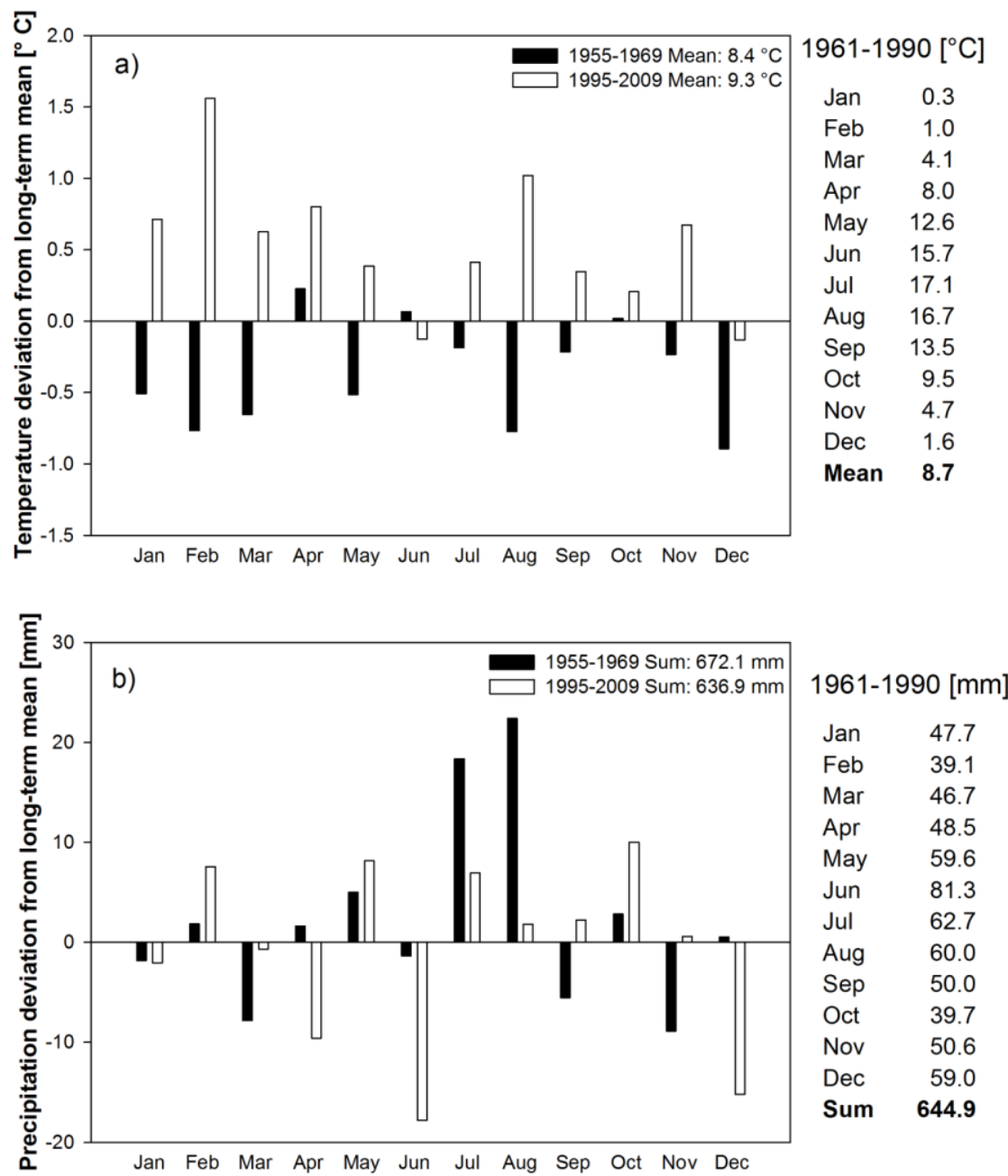

Fig. 1: Deviation of a) the monthly temperature in ${ }^{\circ} \mathrm{C}$ and b) monthly precipitation sum in $\mathrm{mm}$ from the long-term mean (1961-1990) for the periods 1955-1969 and 1995-2009 based on climate data from the weather station Göttingen (173 $\mathrm{m}$ a.s.I.). The monthly temperature values and precipitation sums for the long-term mean are presented at the right of both diagrams. Additionally, the mean annual temperature and the mean annual precipitation sum for the three time periods are given.

tory mainly along the second axis (Fig. 3). MRPP revealed significant differences in DCA plot scores between inventories for both datasets (dataset 1955-60 vs. 2009: $A=0.09, p<0.001$; dataset 1968 vs. 2009: $A=0.06, p=0.04)$. The vector projection of Ellenberg indicator values shows a plot shift towards higher indicator values for nitrogen and moisture and towards lower values for continentality (Fig. 3). These indicator values also show the highest correlation coefficients with either the first or the second ordination axis (Table 1). The comparison of mean cover-weighted indicator values between observations using the Wilcoxon signed ranks test underlines an increase of nitrogen and a decrease of continentality values for the 1955-60 vs. 2009 dataset and the overall comparison. In the smaller dataset only a significant decrease in temperature values from 1968 to 2009 was detected. Combining both datasets the indicator value for reaction as well showed a significant decrease (Table 2). 

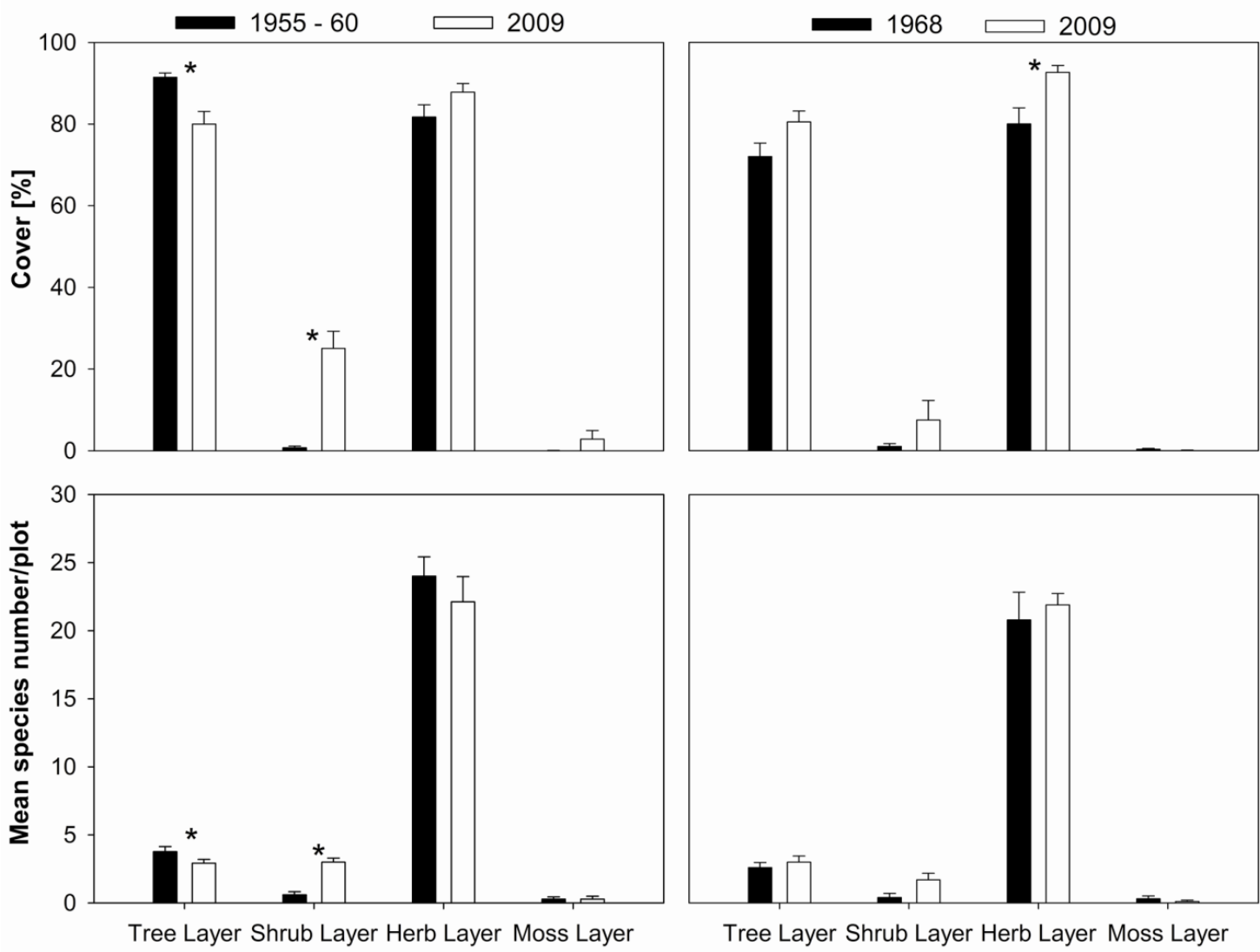

Fig. 2: Cover values and mean species numbers per plot for the four vegetation layers first recorded in either $1955-60$ or 1968 and re-surveyed in 2009. * indicates a significant difference between both inventories according to the Wilcoxon signed ranks test $(p<0.05)$.
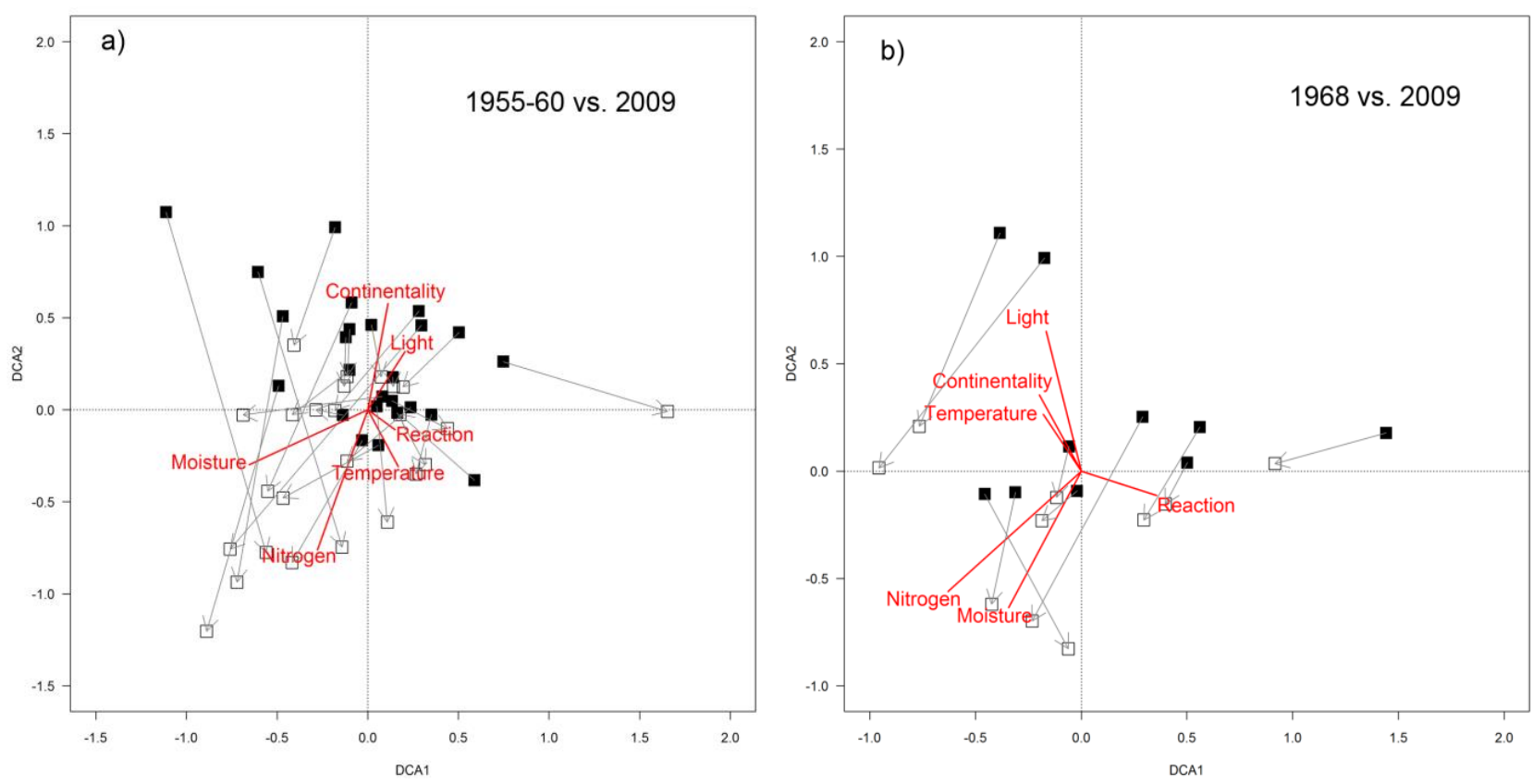

Fig. 3: Detrended correspondence analyses (DCA) with vegetation relevés recorded a) 1955-60 and repeated in 2009 (Axis 1: variance explained $=22 \%$, gradient length $=2.77$ s.d., eigenvalue $=0.24 ;$ Axis 2 : variance explained $=19 \%$, eigenvalue $=0.19$ ) and b) in 1968 and repeated in 2009 (Axis 1: variance explained 49\%; gradient length $=2.40$ s.d., eigenvalue $=0.25$; Axis 2: variance explained $=1 \%$, eigenvalue $=0.21$. Arrows indicate the shift of each plot. The Ellenberg indicator values for light, moisture, nitrogen, temperature, reaction and continentality are projected by using the Pearson correlation of the weighted average of each inventory with its position along the axes 1 and 2 (correlation coefficients are given in Table 1). 
Table 1: Pearson correlation coefficients of mean cover weighted Ellenberg indicator values with the first two axes of the detrended correspondence analyses for the two datasets. ${ }^{*} p<0.05,{ }^{* \star} p<0.01,{ }^{\star \star *} p<0.001$.

\begin{tabular}{|c|c|c|c|c|}
\hline \multirow[b]{2}{*}{ Factor } & \multicolumn{2}{|c|}{$1955-60$ vs. 2009} & \multicolumn{2}{|c|}{1968 vs. 2009} \\
\hline & DCA Axis 1 & DCA Axis 2 & DCA Axis 1 & DCA Axis 2 \\
\hline Moisture & $-0.62^{* * *}$ & -0.39 ** & -0.31 & $-0.40^{* *}$ \\
\hline Continentality & 0.17 & $0.58^{* * *}$ & -0.12 & 0.21 \\
\hline Temperature & 0.22 & $-0.27^{*}$ & -0.19 & 0.12 \\
\hline Light & 0.15 & $0.33^{*}$ & -0.10 & 0.42 \\
\hline Nitrogen & -0.31 * & $-0.80^{* * *}$ & $-0.49^{*}$ & -0.34 \\
\hline Reaction & 0.24 & -0.07 & 0.23 & -0.05 \\
\hline
\end{tabular}

Table 2: Mean unweighted and cover-weighted Ellenberg indicator values for the two datasets and for the combination of both datasets (old surveys vs. new surveys). Differences were analysed using the Wilcoxon signed ranks test. Significant higher values are indicated in bold.

\begin{tabular}{|c|c|c|c|c|c|c|c|c|c|c|c|c|}
\hline & $\begin{array}{r}1955- \\
60\end{array}$ & 2009 & $z$ & $p$ & 1968 & 2009 & $z$ & $p$ & old & new & $z$ & $p$ \\
\hline \multicolumn{13}{|c|}{ Unweighted indicator values: } \\
\hline Moisture & 5.6 & 5.6 & 0.44 & 0.667 & 5.5 & 5.4 & -0.70 & 0.547 & 5.6 & 5.5 & 0.12 & 0.915 \\
\hline Continentality & 3.4 & 3.3 & -2.83 & 0.005 & 3.4 & 3.4 & -1.27 & 0.232 & 3.4 & 3.3 & -3.17 & 0.002 \\
\hline Temperature & 5.4 & 5.4 & -1.43 & 0.157 & 5.5 & 5.4 & -2.09 & 0.037 & 5.5 & 5.4 & -2.45 & 0.014 \\
\hline Light & 3.6 & 3.6 & 0.39 & 0.706 & 3.9 & 3.6 & -1.78 & 0.084 & 3.7 & 3.6 & -0.75 & 0.456 \\
\hline Nitrogen & 6.6 & 6.7 & 2.19 & 0.029 & 6.7 & 6.6 & -0.77 & 0.496 & 6.6 & 6.7 & 1.65 & 0.101 \\
\hline Reaction & 6.9 & 6.8 & -1.68 & 0.095 & 7.0 & 6.9 & -1.58 & 0.131 & 6.9 & 6.8 & -2.24 & 0.025 \\
\hline \multicolumn{13}{|c|}{ Cover-weighted indicator values: } \\
\hline Moisture & 5.7 & 5.8 & 1.12 & 0.247 & 5.7 & 5.8 & 1.58 & 0.131 & 5.7 & 5.8 & 1.75 & 0.081 \\
\hline Continentality & 3.1 & 2.8 & -2.65 & 0.008 & 2.9 & 2.8 & -1.68 & 0.105 & 3.0 & 2.8 & -3.06 & 0.002 \\
\hline Temperature & 5.4 & 5.3 & -0.31 & 0.767 & 5.7 & 5.4 & -2.70 & 0.004 & 5.5 & 5.4 & -1.75 & 0.081 \\
\hline Light & 2.6 & 2.7 & 1.06 & 0.294 & 2.7 & 2.7 & -0.87 & 0.432 & 2.6 & 2.7 & 0.64 & 0.528 \\
\hline Nitrogen & 6.9 & 7.4 & 3.65 & $<0.001$ & 7.3 & 7.4 & 1.78 & 0.084 & 7.0 & 7.4 & 4.078 & $<0.001$ \\
\hline Reaction & 7.2 & 7.1 & -1.20 & 0.236 & 7.3 & 7.1 & -1.58 & 0.131 & 7.2 & 7.1 & -2.00 & 0.047 \\
\hline
\end{tabular}

\section{Single species development}

Several herb layer species showed a significant increase in cover since the recording of the first inventory in 1955-60. This applies to Allium ursinum, Anemone nemorosa, Circaea lutetiana, Leucojum vernum, Hedera helix, Melica uniflora, Brachypodium sylvaticum, Lunaria rediviva, Urtica dioica, Sambucus nigra, Dryopteris carthusiana and D. dilatata. With the exception of A. ursinum, A. nemorosa and $L$. vernum, this increase was accompanied by an increase in frequency. Corydalis cava also increased in cover, though not significantly. Decreasing cover values were detected for Mercu- rialis perennis, Lamium glaeobdolon agg., Arum maculatum and Deschampsia cespitosa. No frequently occurring species disappeared. Despite a decrease in tree layer cover for Fagus sylvatica, the regeneration of this species gained significantly in the shrub layer and nonsignificantly in the herb layer. The same is true for the regeneration of other tree species, particularly $F$. excelsior (Table 3).

The plots first recorded in 1968 and again in 2009 showed a similar development regarding the herb layer species $A$. ursinum, $C$. cava and $M$. perennis (no significant change). However, there was a contrasting development regarding $A$. nemorosa (whose cover and frequency decreased) and L. galeobdolon agg. (whose cover value significantly increased). Ranunculus auricomus agg., Vicia sepium and Phyteuma spicatum disappeared between 1968 and 2009. The tree layer was characterised by an increasing dominance of $F$. sylvatica, which also gained in the herb layer and nonsignificantly in the shrub layer. The regeneration of $F$. excelsior developed in a similar way (Table 4).

Bryophyte species were rarely detected. Appreciable cover values could only be found in 2009 on plots first recorded in 1955-60, but the increase between inventories was not significant (Table 3). 
Table 3: Mean cover ( $\mathrm{mC}$ ) and frequency $(\mathrm{F})$ values of individual species assigned to the tree, shrub, herb, and moss layer on plots first recorded in 1955-60 and re-surveyed in 2009. Only species with a frequency $>20 \%$ or a cover $>1 \%$ in at least one inventory are shown. A cover value $<0.1 \%$ is indicated by + . Significance of differences of cover values between inventories were tested using the Wilcoxon signed ranks test, $p$-values are given, significant higher values are indicated in bold, species with significant increases are highlighted in light grey, species with significant decreases are framed.

\begin{tabular}{|c|c|c|c|c|c|}
\hline \multirow[t]{2}{*}{ Year of survey } & \multicolumn{2}{|c|}{$1955-60$} & \multicolumn{2}{|c|}{2009} & \multirow[b]{2}{*}{$p$-value } \\
\hline & $\mathrm{mC}[\%]$ & $\mathrm{F}[\%]$ & $\mathrm{mC}[\%]$ & $\mathrm{F}[\%]$ & \\
\hline \multicolumn{6}{|l|}{ Tree layer } \\
\hline Fagus sylvatica & 70.0 & 100 & 48.7 & 84 & 0.006 \\
\hline Fraxinus excelsior & 11.3 & 76 & 21.0 & 76 & 0.082 \\
\hline Acer pseudoplatanus & 10.0 & 60 & 16.7 & 56 & 0.193 \\
\hline Acer platanoides & 3.7 & 44 & 5.8 & 24 & 0.966 \\
\hline Tilia platyphyllos & 1.5 & 28 & 4.3 & 20 & 0.203 \\
\hline Carpinus betulus & 1.5 & 24 & 0.2 & 8 & 0.109 \\
\hline Ulmus glabra & 0.9 & 24 & 0.7 & 8 & 0.297 \\
\hline \multicolumn{6}{|l|}{ Shrub layer } \\
\hline Fagus sylvatica & 0.7 & 28 & 5.4 & 68 & 0.004 \\
\hline Acer pseudoplatanus & 0.7 & 12 & 6.3 & 52 & 0.008 \\
\hline Sambucus nigra & 0.2 & 8 & 2.4 & 24 & 0.195 \\
\hline Fraxinus excelsior & 0.1 & 4 & 10.9 & 64 & $<0.001$ \\
\hline Acer platanoides & + & 4 & 1.0 & 28 & 0.023 \\
\hline Ulmus glabra & & & 2.6 & 40 & 0.002 \\
\hline
\end{tabular}

Herb layer

\begin{tabular}{|c|c|c|c|c|c|}
\hline Allium ursinum & 36.6 & 92 & 70.6 & 92 & $<0.001$ \\
\hline Mercurialis perennis & 27.6 & 100 & 16.3 & 84 & 0.007 \\
\hline Lamium galeobdolon agg. & 20.8 & 92 & 9.2 & 76 & 0.011 \\
\hline Galium odoratum & 6.9 & 88 & 3.9 & 64 & 0.174 \\
\hline Asarum europaeum & 5.9 & 80 & 5.1 & 72 & 0.455 \\
\hline Impatiens noli-tangere & 5.1 & 16 & 0.1 & 20 & 0.570 \\
\hline Corydalis cava & 4.5 & 80 & 10.2 & 68 & 0.067 \\
\hline Anemone nemorosa & 3.4 & 68 & 12.6 & 60 & 0.013 \\
\hline Anemone ranunculoides & 3.2 & 96 & 6.9 & 84 & 0.055 \\
\hline Arum maculatum & 3.1 & 92 & 1.4 & 92 & 0.006 \\
\hline Aconitum lycoctonum & 2.5 & 12 & 2.1 & 16 & 1.000 \\
\hline Ranunculus ficaria & 2.0 & 32 & 1.0 & 20 & 0.938 \\
\hline Oxalis acetosella & 1.5 & 36 & 0.6 & 32 & 1.000 \\
\hline Acer pseudoplatanus & 1.4 & 84 & 1.1 & 64 & 0.898 \\
\hline Fraxinus excelsior & 1.4 & 84 & 10.8 & 96 & $<0.001$ \\
\hline Fagus sylvatica & 1.1 & 68 & 2.0 & 64 & 0.306 \\
\hline Hordelymus europaeus & 1.0 & 68 & 1.5 & 44 & 1.000 \\
\hline Stachys sylvatica & 0.9 & 32 & 1.0 & 32 & 0.787 \\
\hline Geranium robertianum & 0.9 & 32 & 0.1 & 12 & 0.160 \\
\hline Acer platanoides & 0.8 & 68 & 1.3 & 60 & 0.135 \\
\hline Primula elatior & 0.7 & 60 & 0.3 & 32 & 0.130 \\
\hline Circaea lutetiana & 0.7 & 16 & 2.8 & 36 & 0.010 \\
\hline Leucojum vernum & 0.5 & 56 & 3.0 & 56 & 0.018 \\
\hline Dryopteris filix-mas & 0.5 & 52 & 1.5 & 60 & 0.064 \\
\hline Viola reichenbachiana & 0.5 & 36 & 0.3 & 20 & 0.063 \\
\hline Cardamine bulbifera & 0.5 & 28 & 0.9 & 44 & 0.109 \\
\hline Gagea lutea & 0.4 & 52 & 0.9 & 24 & 0.903 \\
\hline Ulmus glabra & 0.4 & 44 & 1.0 & 40 & 0.561 \\
\hline Polygonatum multiflorum & 0.4 & 40 & 0.5 & 44 & 0.557 \\
\hline
\end{tabular}


Table 3: continued

\begin{tabular}{|c|c|c|c|c|c|}
\hline \multirow[t]{2}{*}{ Year of survey } & \multicolumn{2}{|c|}{$1955-60$} & \multicolumn{2}{|c|}{2009} & \multirow[b]{2}{*}{$p$-value } \\
\hline & $\mathrm{mC}[\%]$ & $\mathrm{F}[\%]$ & $\mathrm{mC}[\%]$ & $\mathrm{F}[\%]$ & \\
\hline Carex sylvatica & 0.3 & 40 & 0.3 & 28 & 0.970 \\
\hline Hepatica nobilis & 0.3 & 24 & 0.9 & 16 & 0.438 \\
\hline Ranunculus auricomus agg. & 0.2 & 40 & 0.1 & 4 & 0.084 \\
\hline Euphorbia amygdaloides & 0.2 & 36 & 1.9 & 24 & 0.301 \\
\hline Lilium martagon & 0.2 & 32 & 0.2 & 16 & 0.219 \\
\hline Vicia sepium & 0.2 & 24 & 0.2 & 12 & 0.875 \\
\hline Deschampsia cespitosa & 0.1 & 28 & + & 4 & 0.031 \\
\hline Lathyrus vernus & 0.1 & 28 & 0.2 & 12 & 1.000 \\
\hline Alliaria petiolata & 0.1 & 24 & 0.3 & 20 & 0.700 \\
\hline Hedera helix & 0.1 & 20 & 4.0 & 32 & 0.027 \\
\hline Tilia platyphyllos & 0.1 & 16 & 0.1 & 24 & 0.313 \\
\hline Melica uniflora & 0.1 & 12 & 0.5 & 28 & 0.047 \\
\hline Brachypodium sylvaticum & + & 8 & 2.0 & 40 & 0.005 \\
\hline Lunaria rediviva & + & 8 & 5.3 & 24 & 0.031 \\
\hline Urtica dioica & + & 8 & 0.5 & 24 & 0.031 \\
\hline Sambucus nigra & + & 4 & 0.3 & 36 & 0.004 \\
\hline Dryopteris carthusiana & & & 0.2 & 28 & 0.013 \\
\hline Dryopteris dilatata & & & 0.2 & 32 & 0.008 \\
\hline \multicolumn{6}{|l|}{ Moss layer } \\
\hline Fissidens taxifolius & 0.1 & 12 & 1.5 & 4 & 0.875 \\
\hline Eurhynchium swartzii & 0.1 & 8 & 1.2 & 8 & 0.625 \\
\hline Brachythecium rutabulum & & & 1.5 & 8 & 0.500 \\
\hline
\end{tabular}

Table 4: Mean cover $(\mathrm{mC})$ and frequency $(\mathrm{F})$ values of individual species assigned to the tree, shrub and herb layer on plots first recorded in 1968 and re-surveyed in 2009 . Only species with a frequency $>20 \%$ or a cover $>1 \%$ in at least one inventory are shown. A cover value $<0.1 \%$ is indicated by + . Significant differences of cover values between inventories were tested using the Wilcoxon signed ranks test, $p$-values are given, significant higher values are indicated in bold, species with significant increases are highlighted in light grey, species with significant decreases are framed

\begin{tabular}{|c|c|c|c|c|c|}
\hline \multirow[t]{2}{*}{ Year of survey } & \multicolumn{2}{|l|}{1968} & \multicolumn{2}{|c|}{2009} & \multirow[b]{2}{*}{$p$-value } \\
\hline & $\mathrm{mC}[\%]$ & $\mathrm{F}[\%]$ & $\mathrm{mC}[\%]$ & $\mathrm{F}[\%]$ & \\
\hline \multicolumn{6}{|l|}{ Tree layer } \\
\hline Fagus sylvatica & 42.0 & 90 & 56.3 & 90 & 0.031 \\
\hline Carpinus betulus & 13.0 & 40 & 9.3 & 30 & 1.000 \\
\hline Acer platanoides & 7.6 & 30 & 5.5 & 30 & 1.000 \\
\hline Fraxinus excelsior & 7.5 & 50 & 15.8 & 90 & 0.063 \\
\hline Tilia platyphyllos & 4.0 & 20 & 5.3 & 20 & 1.000 \\
\hline Acer campestre & 1.8 & 20 & 5.3 & 20 & 1.000 \\
\hline \multicolumn{6}{|l|}{ Shrub layer } \\
\hline Fagus sylvatica & 0.1 & 10 & 5.8 & 50 & 0.063 \\
\hline Acer pseudoplatanus & & & 1.8 & 20 & 0.500 \\
\hline Fraxinus excelsior & & & 0.6 & 40 & 0.125 \\
\hline \multicolumn{6}{|l|}{ Herb layer } \\
\hline Allium ursinum & 51.5 & 90 & 85.0 & 100 & 0.008 \\
\hline Mercurialis perennis & 34.5 & 80 & 19.3 & 100 & 0.164 \\
\hline Anemone nemorosa & 11.8 & 100 & 5.6 & 50 & 0.008 \\
\hline Corydalis cava & 10.3 & 80 & 16.0 & 70 & 0.313 \\
\hline Arum maculatum & 7.5 & 100 & 0.6 & 80 & 0.002 \\
\hline
\end{tabular}


Table 4: continued

\begin{tabular}{|c|c|c|c|c|c|}
\hline \multirow[t]{2}{*}{ Year of survey } & \multicolumn{2}{|c|}{1968} & \multicolumn{2}{|c|}{2009} & \multirow[b]{2}{*}{$p$-value } \\
\hline & $\mathrm{mC}[\%]$ & $\mathrm{F}[\%]$ & $\mathrm{mC}[\%]$ & $\mathrm{F}[\%]$ & \\
\hline Melica uniflora & 6.1 & 60 & 4.1 & 70 & 0.813 \\
\hline Asarum europaeum & 5.8 & 90 & 2.0 & 80 & 0.109 \\
\hline Ranunculus auricomus agg. & 5.2 & 80 & & & 0.008 \\
\hline Leucojum vernum & 3.1 & 80 & 3.9 & 80 & 1.000 \\
\hline Acer platanoides & 2.9 & 80 & 2.1 & 90 & 1.000 \\
\hline Anemone ranunculoides & 2.6 & 70 & 3.1 & 80 & 0.563 \\
\hline Hepatica nobilis & 2.4 & 70 & 0.4 & 40 & 0.125 \\
\hline Lamium galeobdolon s.str. & 2.0 & 30 & 5.8 & 80 & 0.031 \\
\hline Fraxinus excelsior & 1.9 & 90 & 13.5 & 100 & 0.008 \\
\hline Alliaria petiolata & 1.8 & 30 & 0.1 & 10 & 0.250 \\
\hline Euphorbia amygdaloides & 1.8 & 30 & 0.4 & 30 & 0.625 \\
\hline Cardamine bulbifera & 1.5 & 10 & 0.5 & 20 & 1.000 \\
\hline Galium odoratum & 1.3 & 60 & 4.8 & 100 & 0.031 \\
\hline Acer pseudoplatanus & 1.0 & 70 & 6.0 & 90 & 0.188 \\
\hline Chaerophyllum temulum & 0.9 & 60 & 1.0 & 40 & 1.000 \\
\hline Primula elatior & 0.9 & 50 & 0.1 & 10 & 0.094 \\
\hline Vicia sepium & 0.8 & 40 & & & 0.125 \\
\hline Hordelymus europaeus & 0.7 & 60 & 1.6 & 80 & 0.109 \\
\hline Fagus sylvatica & 0.6 & 30 & 1.7 & 100 & 0.016 \\
\hline Viola reichenbachiana & 0.6 & 30 & 0.4 & 30 & 0.813 \\
\hline Gagea lutea & 0.5 & 50 & 0.7 & 50 & 0.844 \\
\hline Crataegus laevigata & 0.4 & 30 & 0.1 & 10 & 0.250 \\
\hline Hedera helix & 0.4 & 30 & 0.8 & 30 & 0.500 \\
\hline Aconitum lycoctonum & 0.3 & 20 & 0.8 & 30 & 0.500 \\
\hline Dactylis polygama & 0.2 & 30 & 0.1 & 10 & 0.375 \\
\hline Phyteuma spicatum & 0.2 & 30 & & & 0.250 \\
\hline Ulmus glabra & 0.2 & 30 & 0.6 & 30 & 0.438 \\
\hline Polygonatum multiflorum & 0.1 & 10 & 1.4 & 80 & 0.016 \\
\hline Tilia platyphyllos & 0.1 & 10 & 0.2 & 40 & 0.313 \\
\hline Galium aparine & & & 0.8 & 30 & 0.250 \\
\hline Geranium robertianum & & & 0.8 & 40 & 0.125 \\
\hline Impatiens parviflora & & & 0.9 & 50 & 0.063 \\
\hline
\end{tabular}

\section{Discussion}

\section{Tree species development}

The vegetation of beech forests on limestone can be considered as relatively stable due to the longevity of many forest plants. These plants tend to depend on vegetative propagation and consequently, have a low dispersal capacity (Eriksson \& Ehrlén 2006). Thus, to identify an influence of changing abiotic conditions on the vegetation, long-term monitoring on permanent plots is needed to identify decreasing or increasing trends of plant species (Dierschke 2009). In the present study, considering a period of more than 40 years, the vegetation showed several changes in structure and composition that can be attributed to changing abiotic and biotic conditions. The plots first recorded in 1955-60 were affected in recent years by forest management. This can explain a decrease in tree layer coverage and species numbers as the management of these forests was mainly conducted to increase the proportion of commercially valuable broadleaved tree species (e.g. Acer pseudoplatanus, Fraxinus exelsior) at the expense of the dominant beech (Wagenhoff 1975, Meyer et al. 1999). As shown in other studies in forests on limestone, the gap creation by forest management (or by windthrow) promotes natural regeneration especially of beech and ash (Lambertz \& Schmidt 1999, Kompa \& Schmidt 2006). The results presented here are in accordance with these earlier studies.
In contrast, plots of the younger resurvey were less affected by thinning by the forest owners after the first survey, resulting in the dominance of beech and reducing light availability. Nevertheless, tree regeneration in the shrub and herb layer also increased on these plots with time. Half a century ago, the tree regeneration strongly suffered from roe deer browsing which totally excluded the development of a shrub layer (Klötzli 1965, 1978, Eggert 1985). In the last 20 years though, hunting has intensified with 117,000 roe deer shot on average per year compared to a mean of 59,000 per year between 1956 to 1968 in Lower Saxony, reducing browsing intensity and promoting shrub layer development (Niedersäch- 
sisches Ministerium für Ernährung, Landwirtschaft, Verbraucherschutz und Landesentwicklung 2009).

\section{Changes in herb layer species}

Besides the regeneration of valuable broadleaved tree species, herb layer species are also directly affected by browsing and benefit from its reduction (Morgenroth 1992). Anemone nemorosa, A. ranunculoides, Hedera helix and Lamium galeobdolon agg. are all preferred food species (Schmidt 1978, 1988, Gill \& Beardall 2001, Dierschke 2009). In this analysis these species all increased in either one (A. nemorosa, L. galeobdolon agg.) or both datasets (A. ranunculoides). Contrasting developments for A. nemorosa and L. galeobdolon agg. in both datasets can be ascribed to the increasing dominance of Allium ursinum, which reduced other former abundant species like L. galeobdolon agg. on plots first recorded by Winterhoff (1960) or A. nemorosa on plots first surveyed in 1968 (Schmidt 1988, Böhling 2008). Consistent in both datasets is the reduction in cover of M. perennis. Böhling (2008) regards this species as the last antagonist of $A$. ursinum, and it has been observed to gain dominance after the dieback of $A$. ursinum in late spring (Werger \& Van Laar 1985). However, in the Göttinger Wald this species has declined in recent years (Schmidt \& Schmidt 2007, Dierschke 2009, Schmidt 2009). This can be attributed to a reduction in the light availability due to increasing tree regeneration, to fungal infections and to extreme summer dryness, especially in June (Fig. 1b, Schmidt 2009).

\section{The spring geophyte Allium ursinum}

On the other hand, the increase in the spring geophyte Allium ursinum corresponds with results from other German forests (Bücking 1989, Ahrns \& Hofmann 1998, Böhling 2008). Several reasons are mentioned for this spread, such as the eutrophication of forest soils by atmospheric nitrogen deposition (Ahrns \& Hofmann 1998, Bobbink et al. 1998, Brunet et al. 1998, Bernhardt-Römermann et al. 2009). This is supported by concurrent range expansion of the nitrophilous species Urtica dioica and Sambucus nigra on plots first recorded in 1955-60. There is a general shift of the vegetation composition towards species with a higher indicator value for nitrogen in both datasets. A rise in nitrophilous species in recent decades has also been observed in the Netherlands (Tamis et al. 2005), in northern Germany and in Sweden (Diekmann 2010), as well as in the Czech Republic (Chytrý \& Danihelka 1993, Hédl et al. 2010). For Central Europe, Fischer (1999) has summarized results of floristical changes caused by changing site conditions.

Furthermore, A. ursinum may have benefitted from changing microclimatic conditions within the forest. Winterhoff (1977) ascribed the incomplete prevalence of A. ursium in the Göttinger Wald to the formerly used coppice-with-standard system, which is characterised by high light levels on the ground and is therefore, unfavourable for this hygromorphic species. With the change towards high forest, though, the microclimate became darker, reducing the competitiveness of lightdemanding species, as well as cooler and moister, promoting the spread of $A$. ursinum. The development in cover weighted indicator values for temperature (decrease) and moisture (increase) supports the importance of changed microclimatic conditions.

\section{Influence of climate change}

The global climate change might also have positively influenced the spread of A. ursinum. The analysed climate data of Göttingen show that the last 15 years have been characterised by higher temperatures, especially in winter and early spring, compared to fifty years ago. Consequently, the forest soil is warming up earlier. Combined with higher precipitation values in February and March, providing a good water supply, these high temperatures allow an earlier start of the growing season and particularly favour the early starting species A. ursinum, A. nemorosa, A. ranunculoides, $C$. cava and L. vernum. Most of these species increased in mean cover value. Reductions in frequency may be the result of the high competition from $A$. ursinum on some plots (see above). Kirby et al. (2005) showed that 47 of 332 species of British forests were positively influenced by higher spring temperatures. Among these species was A. nemorosa, for which De Frenne et al. (2010) found a positive correlation between higher winter temperatures, an earlier start of the growing season and generative reproduction. Philip \& Petersen (2007) demonstrated positve effects of high winter temperature on the rhizome growth of this spring geophyte. With more precipitation in May, as ob- served in Göttingen, the growing season of these early spring-green species can even be prolonged promoting reproductive success (Böhling 2008). However, considering the reduced precipitation in April, in combination with increased temperatures in the recent decade compared to the long-term mean, soil moisture can as well become a limiting factor for the growth of spring geophytes in the future (Leuschner \& Lenzion 2009).

Hedera helix is another species benefitting from more oceanic conditions with mild winters, though the positive effect of reduced roe deer browsing has as well to be taken into account. This species was already described by Iversen (1944) as a climate indicator that is limited by the absolute value and the duration of low temperatures. In recent years, it showed a spread in the Göttinger Wald (Dierschke 2005). The plots first recorded by Winterhoff (1960) support this trend. Similar observations of this "laurophyllisation" (applying also to the species Ilex aquifolium, Mahonia aquifolium and Vinca minor) have been made in southern Switzerland (Walther \& Grundmann 2001), Great Britain (Kirby et al. 2005), northwestern Germany and Sweden (Diekmann 2010). H. helix is particularly exposed to frost when climbing trees (Dierschke 2005). Thus, in the future, recording the different growth forms would give an even better indication of a climatic influence than just the development of herb layer cover values.

As shown in this study, the detected vegetation dynamics are the result of various interacting abiotic (eutrophication, changes in micro- and macroclimate) and biotic (reduction in roe deer browsing, increased competitiveness of A. ursinum) factors. Hédl et al. (2010) attributed decreases in indicator values for temperature and continentality solely to management changes. It is therefore, almost impossible to identify global climate change as the main driving force of vegetation changes (Huteau \& North 2008). Nevertheless, our data, collected in the Göttinger Wald over half a century, provide further evidence for an influence of mild winters and an earlier start of the vegetation period on forest plant species and supplement the studies from Switzerland, Great Britain or Norway (Walther \& Grundmann 2001, Økland et al. 2004, Kirby et al. 2005). The focus on a rare but very rich sub-unit of beech forests on limestone allows to highlight the uniform reaction of spring geophytes in both datasets, which can be ascribed to changes in climatic conditions. 
These analysed sets of vegetation relevés are, however, only a small part of the present database on "Temperate deciduous forests of the Göttinger Wald". The intended evaluation of the whole community of beech forests on limestone (Hordelymo-Fagetum lathyretosum) in the near future will determine if the detected trends are universal for this community or restricted to its rich sub-unit.

\section{Acknowledgements}

We would like to thank Ruth Gilbert for language correction and Jörg Ewald, Anton Fischer and Radim Hédl for helpful comments and suggestions to improve the paper.

\section{References}

Ahrns, C., Hofmann, G. (1998): Vegetationsdynamik und Florenwandel im ehemaligen mitteldeutschen Waldschutzgebiet „Hainich“ im Intervall 1963-1995. Hercynia N.F. 31: 33-64.

Böhling, N. (2008): Zur Entwicklung der Allium ursinum-Bestände im buchenreichen Eichen-Hainbuchenwald "Hohes Reisach" 1978/2007. - Tuexenia 28: 4149.

Bernhardt, M. (2005): Reaktionen der Waldbodenvegetation auf erhöhte Stickstoffeinträge - Analyse und Vorhersage von Vegetationsveränderungen anhand von funktionellen Merkmalen. Dissertationes Botanicae 397: 1-121.

Bernhardt-Römermann, M., Pfadenhauer, J., Östreicher, S., Fischer, A. (2009): Stickstoffbedingte Vegetationsveränderungen in einem EichenHainbuchenwald - Ergebnisse aus 18 Jahren Dauerbeobachtung. - Forstarchiv 80: 181-188.

Bobbink, R., Hornung, M., Roelofs, J.G.M. (1998): The effects of air-borne nitrogen pollutants on species diversity in natural and semi-natural European vegetation. Journal of Ecology 86: 717-738. CrossRef

Bradshaw, R.H.W., Zackrisson, O. (1990): A two thousand year history of a northern Swedish boreal forest stand. - Journal of Vegetation Science 1: 519-528. CrossRef

Braun-Blanquet, J. (1964): Pflanzensoziologie. 3rd ed. - Berlin: Springer. CrossRef

Brunet, J., Diekmann, M., FalkengrenGrerup, U. (1998): Effects of nitrogen deposition on field layer vegetation in south Swedish oak forests. - Environmental Pollution 102 S1: 35-40. $\underline{\text { CrossRef }}$
Bücking, W. (1989): Bannwald Bechtaler Wald. Dauerbeoachtungen 1970-1988. - Natur und Landschaft 64: 574-577.

Campbell, I.D., McAndrews, J.H. (1993): Forest disequilibrium caused by rapid Little Ice Age cooling. - Nature 366: 336-338. CrossRef

Carraro, G., Gianoni, P., Mossi, R., Klötzli, F., Walther, G.-R. (2001): Observed changes in vegetation in relation to climate warming. - In: Burga, C.A., Kratochwil, A. [Eds.]: Biomonitoring - general and applied aspects on regional and global scales: 195-205. Dordrecht: Kluwer Academic Publishers.

Chytrý, M., Danihelka, J. (1993): Longterm changes in the field layer of oak and oak-hornbeam forests under the impact of deer and mouflon. - Folia Geobotanica et Phytotaxonomica 28 : 225-245.

De Frenne, P., Graae, B.J., Kolb, A., Brunet, J., Chabrerie, O., Cousins, S.A.O., Decocq, G., Dhondt, R., Diekmann, M., Eriksson, O., Heinken, T., Hermy, M., Jõgar, Ü., Saguez, R., Shevtsova, A., Stanton, S., Zindel, R., Zobel, M., Verheyen, K. (2010): Significant effects of temperature on the reproductive output of the forest herb Anemone nemorosa L. - Forest Ecology and Management 259: 809-817. CrossRef

Dengler, J., Jansen, F., Glöckler, F., Peet, R.K., De Cáceres, M., Chytrý, M., Ewald, J., Oldeland, J., Finckh, M., Lopez-Gonzalez, G., Mucina, L., Rodwell, J.S., Schaminée, J.H.J., Spencer, N. (2011): The Global Index of VegetationPlot Databases (GIVD): a new resource for vegetation science. - Journal of Vegetation Science 22: 582-597. CrossRef

Diekmann, M. (2010): Aktuelle Vegetationsveränderungen in Wäldern - Welche Rolle spielt der Klimawandel? - Berichte der Reinhold-Tüxen-Gesellschaft 22: $57-65$.

Diekmann, M., Dupré, C. (1997): Acidification and eutrophication of deciduous forests in north-western Germany demonstrated by indicator species analysis. Journal of Vegetation Science 8: 855864. CrossRef

Dierschke, H. (1989): Artenreiche Buchenwald-Gesellschaften NordwestDeutschlands. - Berichte der Reinhold Tüxen-Gesellschaft 1: 107-148.

Dierschke, H. (1994): Pflanzensoziologie. - Stuttgart: Ulmer.

Dierschke, H. (2000): Phenological phases and phenological species groups of mesic beech forests and their suitability for climatological monitoring. - Phytocoenologia 30: 469-476.

Dierschke, H. (2005): Laurophyllisation auch eine Erscheinung im nördlichen Mitteleuropa? Zur aktuellen Ausbreitung von Hedera helix in sommergrünen Laubwäldern. - Berichte der ReinholdTüxen-Gesellschaft 17: 151-168.
Dierschke, H. (2009): Vegetationsdynamik in einem gezäunten naturnahen Kalkbuchenwald. Vergleich von Vegetationsaufnahmen 1980 und 2001. - Forstarchiv 80: 143-150.

Eggert, A. (1985): Zur Ökologie der Krautschichtvegetation in einem BärlauchKalkbuchenwald. - PhD thesis, University of Göttingen.

Ellenberg, H., Weber, H.E., Düll, R., Wirth, V., Werner, W. (2001): Zeigerwerte von Pflanzen in Mitteleuropa. - Scripta Geobotanica 18: 1-262.

Eriksson, O., Ehrlén, J. (2006): Long-term dynamics of herb populations in Swedish deciduous forests: some generalizations. - Polish Botanical Studies 22: 185-194.

Falkengren-Grerup, U. (1986): Soil acidification and vegetation changes in deciduous forest in southern Sweden. Oecologia 70: 339-347. CrossRef

Fischer, A. (1999): Floristical changes in Central European forest ecosystems during the past decades as an expression of changing site conditions. - In: Karjalainen, T., Spiecker, H., Laroussinie, O. [Eds.]: Causes and consequences of accelerating tree growth in Europe. - EFI Proceedings 27: 53-64.

Fitter, A.H., Fitter, R.S.R. (2002): Rapid changes in flowering time in British plants. - Science 296: 1689-1691. CrossRef

Gill, R.M.A., Beardall, V. (2001): The impact of deer on woodlands: the effects of browsing and seed dispersal on vegetation structure and composition. - Forestry 74: 209-218. CrossRef

Hédl, R., Kopecký, M., Komárek, J. (2010): Half a century of succession in a temperate oakwood: from species-rich community to mesic forest. - Diversity and Distributions 16: 267-276.

Hilker, N., Rigling, A., Dobbertin, M. (2005): Mehr Misteln wegen der Klimaerwärmung? - Wald und Holz 3: 39-42.

Huntley, B. (1990): European post-glacial forests: compositional changes in response to climatic change. - Journal of Vegetation Science 1: 507-518. CrossRef

Hurteau, M., North, M. (2008): Mixedconifer understory response to climate change, nitrogen, and fire. - Global Change Biology 14: 1543-1552. Cross$\underline{\text { Ref }}$

Iversen, J. (1944): Viscum, Hedera and Ilex as climate indicators. - Geologiska Föreningens i Stockholm Förhandlingar 66: 463-483. CrossRef

Jansen, F., Dengler, J., Glöckler, F., Chytrý, M., Ewald, J., Oldeland, J., Schaminée, J.H.J. (2011): Die mitteleuropäischen Datenbanken im Global Index of Vegetation-Plot Databases (GIVD). - Tuexenia 31: 351-367.

Kirby, K.J., Smart, S.M., Black, H.I.J., Bunce, R.G.H., Corney, P.M., Smithers, R.J. (2005): Long term ecological 
change in British woodland (1971-2001) - A re-survey and analysis of change based on the 103 sites in the Nature Conservancy 'Bunce 1971' woodland survey. - English Nature Research Reports 653: 1-139.

Klötzli, F. (1965): Qualität und Quantität der Rehäsung in Wald- und GrünlandGesellschaften des nördlichen Schweizer Mittellandes. - PhD thesis, Technische Hochschule Zürich.

Kompa, T., Schmidt, W. (2006): Zur Verjüngungssituation in südniedersächsischen Buchen-Windwurfgebieten nach einem lokalen Orkan von 1997. - Forstarchiv 77: 3-19.

Koperski, M. (1999): Florenliste und Rote Liste der Moose in Niedersachsen und Bremen. - Informationsdienst Naturschutz Niedersachsen 19: 1-76.

Lambertz, B., Schmidt, W. (1999): Auflichtungen in Buchen- und Buchenmischbeständen auf Muschelkalk und Buntsandstein - Untersuchungen zur Verjüngungs- und Vegetationsstruktur. - Verhandlungen der Gesellschaft für Ökologie 29: 81-88.

Lenoir, J., Gégout, J.C., Marquet, P.A., de Ruffray, P., Brisse, H. (2008): A significant upward shift in plant species optimum elevation during the 20th century. - Science 320: 1768-1771. CrossRef

Lenoir, J., Gégout, J.C., Dupouey, J.L., Bert, D., Svenning, J.-C. (2010): Forest plant community changes during 19892007 in response to climate warming in the Jura Mountains (France and Switzerland). - Journal of Vegetation Science 21: 949-964. CrossRef

Lesica, P., McCune, B. (2004): Decline of arctic-alpine plants at the southern margin of their range following a decade of climate warming. - Journal of Vegetation Science 15: 679-690. CrossRef

Leuschner, C., Lendzion, J. (2009): Air humidity, soil moisture and soil chemistry as determinants of the herb layer compositions in European beech forests. - Journal of Vegetation Science 20: 288-298. CrossRef

McCune, B., Grace, J.B. (2002): Analysis of ecological communities. - Oregon, USA: MjM Software Design.

Menzel, A., Sparks, T.H., Estrella, N., Koch, E., Aasa, A., Alm-Kübler, K., Bissolli, P., Braslavská, O., Briede, A., Chmielewski, F.M., Crepinsek, Z., Curnel, Y., Dahl, Å., Defila, C., Donnelly, A., Filella, Y., Jatczak, K., Måge, F., Mestre, A., Nordli, Ø., Peñuelas, J., Pirinen, P., Remišová, V., Scheifinger, H., Striz, M., Susnik, A., Van Vliet, A.J.H., Wielgolaski, F.E., Zach, S., Zust, A. (2006): European phenological response to climate change matches the warming pattern. - Global Change Biology 12: 1969-1976. CrossRef

Meyer, P., Guericke, M., Hillebrand, K. (1999): Eigendynamische und gesteuerte Waldentwicklung im Kalk-
Buchenwald. Ein Vergleich des Naturwaldes Hünstollen und der Wuchsreihe Buche/Edellaubbäume im Forstamt Bovenden. - Forst und Holz 54: 48-54.

Morgenroth, K. (1992): Der Einfluß des Rehwildes auf die Vegetation des Göttinger Kalkbuchenwaldes. - Diplom thesis, Universität Göttinigen.

Niedersächsisches Ministerium für Ernährung, Landwirtschaft, Verbraucherschutz und Landesentwicklung (2009): Wild und Jagd - Landesjagdbericht 2008. Hannover: Niedersächsisches Ministerium für Ernährung, Landwirtschaft, Verbraucherschutz und Landesentwicklung.

Økland, T., Bakkestuen, V., Økland, R.H., Eilertsen, O. (2004): Changes in forest understorey vegetation in Norway related to long-term soil acidification and climate change. - Journal of Vegetation Science 15: 437-448.

Oksanen, J., Kindt, R., Legendre, P., O'Hara, B., Simpson, G.L., Stevens, M.H.H., Wagner, H. (2008): Vegan: community ecology package. - URL: http://vegan.r-forge.r-project.org.

Overpeck, J.T., Rind, D., Goldberg, R. (1990): Climate-induced changes in forest disturbance and vegetation. - Nature 343: 51-53. CrossRef

Panferov, O., Kreilein, H., Meesenburg, H., Eichhorn, J., Gravenhorst, G. (2009) Climatic conditions at three beech forest sites in central Germany. - In: Brumme, R., Khanna, P.K. [Eds.]: Functioning and management of European beech ecosystems. - Ecological Studies 208: 1332. Heidelberg: Springer-Verlag.

Pauli, H., Gottfried, M., Reiter, K., Klettner, C., Grabherr, G. (2007): Signals of range expansions and contractions of vascular plants in the high Alps: observations (1994-2004) at the GLORIA master site Schrankogel, Tyrol, Austria. - Global Change Biology 13: 147-156. CrossRef

Philipp, M., Petersen, P.M. (2007): Longterm study of dry matter allocation and rhizome growth in Anemone nemorosa. - Plant Species Biology 22: 23-31. CrossRef

R Development Core Team (2008): R: A language and environment for statistical computing. R Foundation for Statistical Computing, Vienna, Austria. - URL: http://www.R-project.org.

Röder, H., Fischer, A., Klöck, W. (1996): Waldentwicklung auf Quasi-Dauerflächen im Luzulo-Fagetum der Buntsandsteinrhön (Forstamt Mittelsinn) zwischen 1950 und 1990. - Forstwissenschaftliches Centralblatt 115: 321-335.

Root, T.L., Price, J., Hall, K.R., Schneider, S.H., Rosenzweig, C., Pounds, J.A. (2003): Fingerprints of global warming on wild animals and plants. - Nature 421: 57-60. CrossRef

Schmidt, M., Schmidt, W. (2007): Vegetationsökologisches Monitoring in Natur- waldreservaten. - Forstarchiv 78: 205214.

Schmidt, W. (1968): Phosphatgehalt und Säuregrad des Bodens in Beziehung zum Artengefüge von Buchenwäldern um Göttingen. - Examination thesis, University of Göttinigen.

Schmidt, W. (1978): Einfluß einer Rehpopulation auf die Waldvegetation - Ergebnisse von Dauerflächenversuchen im Rehgatter Stammham 1972-1976. Phytocoenosis 7: 43-59.

Schmidt, W.(1988): Langjährige Veränderungen der Krautschicht eines Kalkbuchenwaldes. - Tuexenia 8: 327-338.

Schmidt, W. (2009): Vegetation. - In: Brumme, R., Khanna, P.K. [Eds.]: Functioning and management of European beech ecosystems. - Ecological Studies 208: 65-86. Heidelberg: SpringerVerlag.

Schmidt, W., Dölle, M, Parth, A. (2012): Vegetation Database of Temperate Deciduous Forests of the Göttinger Wald In: Dengler, J., Oldeland, J., Jansen, F., Chytrý, M., Ewald, J., Finckh, M., Glöckler, F., Lopez-Gonzalez, G., Peet, R.K., Schaminée, J.H.J. [Eds.]: Vegetation databases for the 21 st century. - Biodiversity \& Ecology 4: 359-359. Hamburg: Biocentre Klein Flottbek and Botanical Garden. CrossRef

Sparks, T.H., Jaroszewicz, B., Krawczyk, M., Tryjanowski, P. (2009): Advancing phenology in Europe's last lowland primeval forest: non-linear temperature response. - Climate Research 39: 221226. CrossRef

Tamis, W.L.M., Van't Zelfde, M., Van der Meijden, R., De Haes, H.A.U. (2005): Changes in vascular plant biodiversity in the Netherlands in the $20^{\text {th }}$ century explained by their climatic and other environmental characteristics. - Climate Change 72: 37-56. CrossRef

Van der Veken, S., Bossuyt, B., Hermy, M. (2004): Climate gradients explain changes in plant community composition of the forest understorey: an extrapolation after climate warming. - Belgian Journal of Botany 137: 55-69.

Von Oheimb, G., Schmidt, M., Kriebitzsch, W.U., Ellenberg, H. (2005): Dispersal of vascular plants by game in northern Germany. Part II: Red deer (Cervus elaphus). - European Journal of Forest Research 124: 55-65. CrossRef

Wagenhoff, A. (1975): Die Wirtschaft in Edellaubholz/Buchen-Mischbeständen auf optimalen Standorten im Forstamt Bovenden. - Aus dem Walde 24: 5-60.

Walther, G.-R. (2010): Community and ecosystem responses to recent climate change. - Philosophical Transactions of the Royal Society B 365: 2019-2024. CrossRef

Walther, G.-R., Grundmann, A. (2001): Trends of vegetation change in colline and submontane climax forests in Swit- 
zerland. - Bulletin of the Geobotanical Institute ETH 67: 3-12.

Walther, G.-R., Berger, S., Sykes, M.T. (2005a): An ecological 'footprint' of climate change. - Proceedings of the Royal British Society B 272: 1427-1432. CrossRef

Walther, G.-R., Beißner, S., Burga, C.A. (2005b): Trends in the upward shift of alpine plants. - Journal of Vegetation Science 16: 541-548. CrossRef

Walther, G.-R., Gritti, E.S., Berger, S., Hickler, T., Tang, Z., Sykes, M.T. (2007): Palms tracking climate change. - Global Ecology and Biogeography 16: 801809. CrossRef

Werger, M.J.A., Van Laar, E.M.J.M. (1985): Seasonal changes in the struc- ture of the herb layer of a deciduous woodland. - Flora 176: 351-364.

Winterhoff, W. (1960): Die Waldgesellschaften des Göttinger Waldes. Examination thesis, University of Göttingen.

Winterhoff, W. (1977): Über Verbreitungslücken einiger Arten im Göttinger Wald. - Mitteilungen der FloristischSoziologischen Arbeitsgemeinschaft N.F. 19/20: 365-375.

Wisskirchen, R., Haeupler, H. (1998): Standardliste der Farn- und Blütenpflanzen Deutschlands. - Stuttgart: Ulmer.

Wohlgemuth, T., Conedera, M., Kupferschmid Albisetti, A., Moser, B., Usbeck, T., Brang, P., Dobbertin, M. (2008): Effects of climate change on windthrow, forest fire and forest dynamics in Swiss forests. - Schweizer Zeitschrift für Forstwesen 159: 336-343. CrossRef

Steffi Heinrichs* (sheinri@gwdg.de) \& Wolfgang Schmidt (wschmid1@gwdg.de) Department Silviculture and Forest Ecology of the Temperate Zones, GeorgAugust-University Göttingen Büsgenweg 1 37077 Göttingen, GERMANY

Wulfard Winterhoff

(winterhoffsandhausen@gmx.de)

Keplerstr. 14

69207 Sandhausen, GERMANY

*Corresponding author 
